\title{
Sustainable tourism development in AlFayoum Oasis, Egypt
}

\author{
Y. H. Ramzy \\ Hotels and Tourism Department, Arab Academy for Science, Technology \\ and Maritime Transport, Egypt
}

\begin{abstract}
Sustainability has become an important concept for tourism development all over the world. Egypt has witnessed a severe reduction in the flow of tourists after the revolutionary wave of the Arab Spring. Nowadays, the country is taking several steps to diversify its tourism product. Beside its traditional tourism products, Egypt is required to develop new products in order to enrich the tourism industry, such as ecotourism in desert areas. Additionally, as one of the effective diversification methods of tourism products is to integrate tourism product each with different characteristics. In fact, Egypt embraces several tourist areas that are not yet exploited, in spite of the fact that they possess all the potentials to be an attractive tourist area. One of these places is AlFayoum. AlFayoum is a beautiful oasis that is endowed with rich natural and cultural heritage. However, the vast potentials it holds has not yet transformed into economic value. The purpose of this research is to highlight the present tourism resources in the oasis and the problems that hinder its development. The research also aims to understand how sustainability can be applied on the tourist attractions and how these resources can be managed efficiently and effectively.

Keywords: sustainable development, ecotourism, AlFayoum Oasis, Egypt, protected areas.
\end{abstract}

\section{Introduction}

Tourism has always been one of the main sources of income in Egypt, but the January $25^{\text {th }}$ revolution in 2011 disrupted the industry. In fact, Egypt's tourism sector underwent unprecedented circumstances and experienced a huge crisis, which resulted from the dramatic regional and local political changes. The tragic 
aftermath of the Arab Spring revolutions in the Middle East and North Africa countries in general and the January $25^{\text {th }}$ specifically constituted the biggest challenge, which faced Egypt's tourism. In fact, the tourist flow dropped by about $45 \%$ to reach less than 9 million, Bly [1] compared to over 14 million in 2010 (UNWTO [2]). Additionally, the country witnessed a sharp decline in the operation of all the tourism industry sectors from hotel accommodation to car rental agencies. Consequently, according to 2011 report of International Tourism Organization, Egypt has left the club of the 20 top tourism countries, which it had joined in 2010. As unrest continuous in the country, with violence erupting at the end of 2012, the country is trying to move toward slow growth to gradually return to pre- crisis levels.

Tourism is undoubtedly an important domain for economic development in Egypt and should be properly encouraged and promoted. Indeed, almost 95\% of tourism activity in Egypt is leisure and culture oriented and mostly concentrated on Cairo, Upper Egypt, Sinai and the Red Sea. Indeed, if the economic development of a certain country is to be based to some extent on tourism, therefore diversification of the tourist product via alternative forms of tourism is a very appropriate strategy. Sustainable tourism is potentially significant force in shaping the economic and societal development. Nowadays it is very important to develop and manage sustainable tourism opportunities and this should only be planned through exploiting new touristic areas and introducing new forms of tourism.

The environment is the main pillar for the natural and cultural resources for attracting tourists. The environmental protection and conservation is essential for the success of sustainable tourism development. Any tourism destination should manage its environmental resources in order to exploit it without causing negative impacts on these resources, decreasing the level of tourists' satisfaction, or causing socioeconomic problems for the local community. Therefore, it is important to plan and develop a form of tourism that is environmentally friendly; because the protection of the environment is usually considered one of the least important concerns for mass tourism. Indeed, the best form of tourism in this case is the concept of "ecotourism". Additionally, one of these areas that can be planned and developed sustainably as a tourist area is AlFayoum oasis.

\section{Ecotourism as a sustainable development approach}

Ecotourism has become an important economic activity in natural areas around the world. It is one of the most important new tourism development approaches. It has the potential of yielding enriched travel experiences and generating enormous revenues. Additionally, it provides opportunities for visitors to experience powerful manifestations of nature and culture and to learn about the importance of biodiversity conservation and local cultures (Drum et al. [3]). At the same time, ecotourism generates income for conservation programs and economic benefits for communities living in rural and remote areas. However, it can also be potentially damaging both to the environment and to the national economy in the long run. 
Indeed, ecotourism is primarily a nature- based industry developed to foster an ecologically sustainable mode of "tourism". It involves travelling to relatively undistributed areas to enjoy the scenery with its wild plants and animals as well as any existing culture manifestations. Additionally, ecotourism is more than visiting National parks and travelling to un-spoilt natural areas. The ecotourism industry has developed to cater for tourists with an interest in the environment a desire to learn, to appreciate, to understand and to conserve (Tourism Western Australia [4]).

Furthermore, ecotourism describes policies, practices and programmes that take into account not only the expectations of tourists regarding responsible natural resource management, but also the needs of communities that support or are affected by tourism projects and the environment. Ecotourism thus aspires to be more energy efficient and more "climate sound" (e.g. by using renewable energy); consume less water; minimise waste; conserve biodiversity, cultural heritage and traditional values; support intercultural understanding and tolerance; and generate local income and integrate local communities with a view to improving livelihoods and reducing poverty (UNEP [5]).

However, planning for ecotourism is relatively a difficult task. This is due to several factors. The first factor is the complex relationship between tourism and the environment. The relationship between tourism and the environment is unbalanced. Indeed, tourism is environmentally dependent and the environment is vulnerable to the impact of tourism" (Wong [6]). The second factor, the multidisciplinary nature of sustainable development in general and ecotourism in particular. Sustainable tourism implies accounting for the intergenerational impacts of tourism. Accounting for intergenerational impacts requires encompassing economic, political, social, cultural, ecological, and geographical characteristics into sustainable tourism development (Aronsson [7]). The third factor is the diversity of stakeholders involved in planning and managing ecotourism. Several parties affect and are affected by tourism performance, policy and planning. The most influential stakeholders in tourism from an environmental perspective are found to be the government, private sector organizations, tourists, competitors, employees and other suppliers (Alvarez et al. [8]).

As a matter of fact, the success of ecotourism resources management will depend on the extent to which undesirable environmental effects of tourism development and tourist activities are prevented or minimised in order to guarantee a certain level of quality of life to the local community. Additionally, successful environmental strategy forces those who profit from tourism to participate in the policies and procedures implemented to overcome environmental costs. These are mainly the private sector organizations, because they gain the highest percentage of profit. They should be responsible for assuming greater environmental responsibility. 


\section{Ecotourism and sustainable development in Egypt}

Egypt has a great potential for ecotourism. This is because Egypt is rich with its natural resources and archaeological sites. Egypt's interest in sustainable tourism development is essential because the country is quickly learning the need for balancing between the environment and development, amid concerns that tourism is stressing the country's fragile ecosystem. Indeed, Pásková [9] stated that unregulated tourism is usually unfriendly towards the natural environment because with an excessive intensity and pace, it consumes especially nonrenewable resources.

Moreover, the Egyptian tourism industry invokes changes in the environment directly, it has dealt with changes invoked directly by the development of tourism, but also indirectly, by consumption of resources which were produced, created and exploited for tourism (Antouskova et al. [10]). In Egypt, ecotourism is a way of managing all resources that economic, social and aesthetic needs would be met, while maintaining cultural integrity, ecological environment and biological diversity and life support systems (Vaško [11]). Accordingly, Egypt should focus on improving the quality rather than increasing the quantity of tourism. Indeed, sustainable development in Egypt requires that environmental considerations become a main focus of the decision- making process (Schmidheiny [12]).

In Egypt, sustainable tourism refers to projects and initiatives operated by private business, organizations and government bodies. However, these projects and initiatives were not successful and the negative impact of tourism is apparent. The Egyptian government is starting to take actions towards sustainability efforts. Nowadays the government is trying to assume full environmental responsibility, which often conflict with tourism development goals of creating job opportunities and increasing foreign currency. Government supervision is essential in this case because the private sector cannot be relied on because its activity is profit oriented.

Moreover, the Egyptian ministry of tourism believes that tourism can and should benefit the environment if practiced in a sustainable manner by promoting Eco destinations and raising awareness. It also believes that the environment is an asset that must be protected and wisely utilized. Additionally, the ministry of tourism has taken serious actions for this by establishing a department inside it to promote ecotourism and sustainable development in 2011.

Ecotourism in Egypt is concentrated mainly in three areas. These are the eastern desert, the protected areas of the western deserts and the oasis and finally the Sinai desert. All of these areas are rich with a mixture of biodiversity. As a matter of fact, ecotourism gives the opportunity for the Egyptian government to develop unutilized lands. Moreover, protected areas are fundamental tool used in Egypt for protecting natural resources. This is because they create a buffer and refuge against rising tide of human impacts (EEAA [13]). Egypt embraces 29 protected areas declared by law, which occupies $15 \%$ of the total area of Egypt. Indeed, once an area has been designated as a protected area by prime Ministerial decree, the protected area is considered as a priority because of their value as a 
resource for scientific research, biodiversity and ecotourism. The Egyptian protected areas are a valuable asset and could be a great resource if well protected and soundly.

AlFayoum Oasis was chosen for this research because it is the largest oasis in Egypt. It is rich with its natural and archaeological resources and is still undeveloped. Indeed, AlFayoum Oasis is a promising area that has all potentials to be a famous ecotourism area in Egypt.

\section{AlFayoum Oasis: a potential ecotourism destination}

AlFayoum, a green oasis and a governorate, is located in the heart of Egypt, between the Nile Delta and Upper Egypt. It is located in the north of Western Desert and 90 kilometres southwest of Cairo. Indeed, AlFayoum benefits significantly from its proximity to Cairo and it is accessible through several wellpaved highways (see Figure 1). Hence came the city's name "AlFayoum" which was changed by Arabs from the original Coptic name "Efium" which means the sea or the lake. Administratively AlFayoum is further divided into six districts (Markaz), Tamiah, Senores, AlFaiyum, Abshway, Etsa and Yosuf El Siddique with six main cities and more than 150 rural villages. The total population of Faiyum governorate is estimated to be 2.48 million in 2005. The GDP per capita according to UNDP Human Development Report is \$ 3,301.8 (EMU and EEAA [14]).

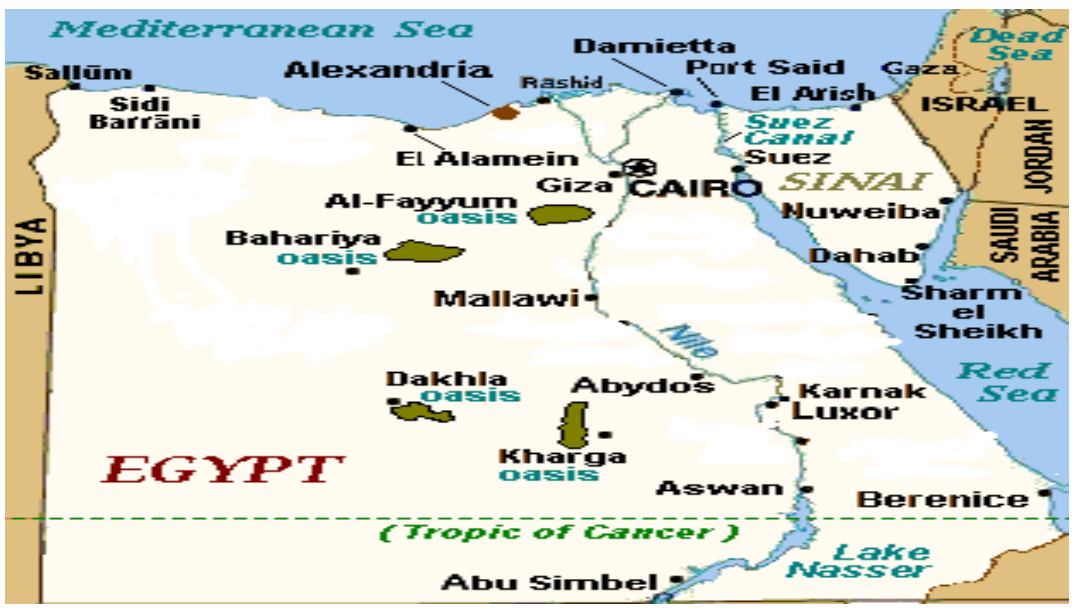

Figure 1: $\quad$ Location of AlFayoum.

AlFayoum occupies significant place in the history of Egypt. From prehistory up until modern times AlFayoum has attracted attention of dynasties, rulers and invaders, historians and explorers, researchers and archaeologists since circa 3000 BC. AlFayoum remained famous for its agricultural yield and royal hunting ground for centuries which left imprints in the form of monuments. AlFayoum 
saw many dynasties beginning from the old kingdom, middle kingdom, and Ptolemaic, Roman, Byzantine periods to Arab conquest in 640-41 followed by Fatimids, Mameluks and Ottomans, Napoleon (1798-1801) and last but not least British rule that ended during the middle of the 20th century (Santagata et al. [15].)

All this blessed AlFayoum with natural and cultural endowments. Al Fayoum is considered one of the most important tourist areas as it comprises tourism attraction elements, the most significant of which is the meeting between the three agricultural, coastal and desert environments. The abundance of archaeological monuments of unmatched significance, lakes, fossils, desert, fertile agricultural land, its unique flora and fauna, and water management system through the historic network of canals together with its three distinctive human cultures - peasant, fishermen and Bedouin - make AlFayoum significant with high cultural and historic values. However, the vast potential it holds has not yet been transformed into economic value. Additionally, the diversity of AlFayoum's ecosystem provides huge potential for combining different types of tourism products in the same area. AlFayoum is a magnificent blend of desert, green oasis and lake.

Al Fayoum oasis is also a promising area that has all potentials to be a famous ecotourism area in Egypt. The government has already declared three protected areas in it, as in 1989, Lake Qarun and Wadi El Rayan. Now, the two protectorate areas offer a good opportunity to support ecotourism development in AlFayoum. Furthermore, one of the unique sites in AlFayoum Oasis which is; Whale Valley "Wadi El Hitan" is declared by the UNESCO as a world heritage site in 2005 (Eraqi [16]). Since the Declaration of Wadi Hitan as the World Heritage Site in 2005, it is the beginning of recognition of the significance that AlFayoum holds (see Figure 2).

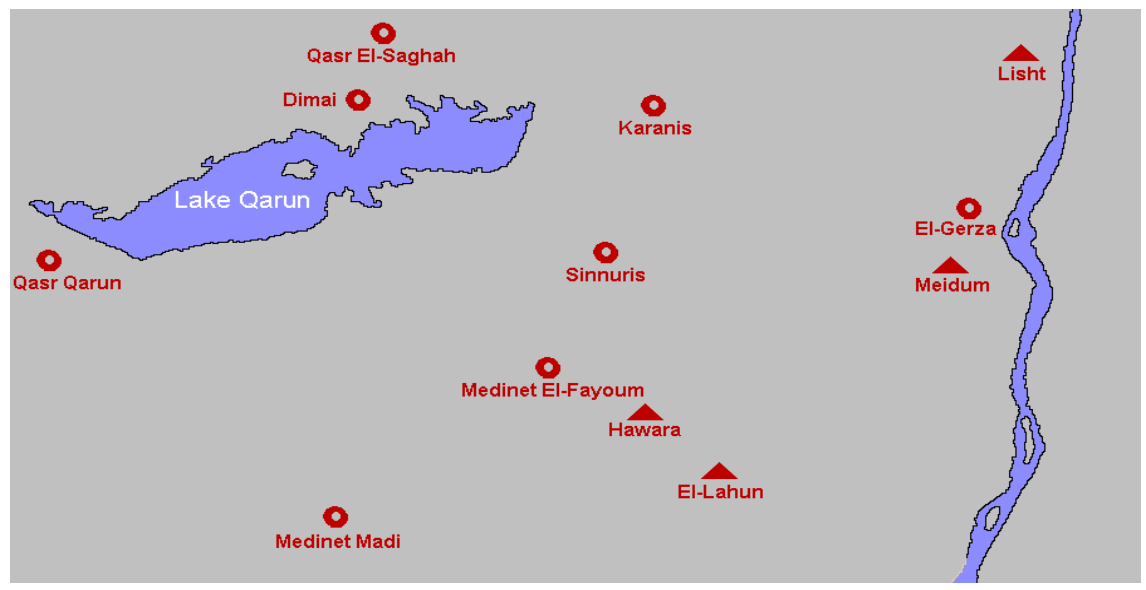

Figure 2: Main areas in AlFayoum. 
Moreover, the national recognition embodied in declared protected areas serves as an important draw for tourism to the region. Tourism centers located near protected areas benefit from many marketing and promotional opportunities. The trails, information centers, signs and other infrastructure of the protected areas become destination attractions for the tourism center resorts. Ecotourism opportunities as well as opportunities for Eco- lodge development are made possible (TDA [17]). However, the protected areas in AlFayoum are of the most highly threatened protected areas in the country, primarily due to its proximity to Cairo but also to the very sensitive nature of its desert flora, fauna and fossil deposits (EEAA [13]).

\subsection{Lake Qarun protected area}

It is the first declared protected area. Lake Qarun was declared a nature reserve with a view to protecting and conserving the biological, archaeological and geological diversity of the area. It has an area of 230 square kilometers. It was declared as a natural reserve in 1989. The main objective of this protected area is the protection of marine and terrestrial wildlife. The Lake could also be considered as a wetland of international importance because of the presence of water birds.

The lake is the third largest in Egypt. A small island, Gezert El Qarn El Zahbi (Qarn Island), is located in the middle of Lake Qarun covering an area of about $1.5 \mathrm{~km}^{2}$, and it is considered as one of most attractive site for nesting birds. Lake Qarun, is one of the oldest lakes in Egypt. Lake Qarun is a safe haven and warm cradle for thousands of migrant birds fleeing the severe cold of Europe. It is also the incubator and the happy nest that embraces infant birds on the lake islets during reproduction time. Various kinds of fish live in the lake waters, while many species of mammals and reptiles live in this wonderful area.

\subsection{Wadi EIRayan protected area}

Wadi El-Rayan has an area of 1759 square kilometres. The area has a special historical significance as a major cross road that was used for many centuries by travelers between the Nile Valley and the oases of the Western Desert. Indeed, the remains of the human settlements from Egyptian and Roman- Greek eras are found in the area.

Wadi ElRayan is composed of an Upper lake $\left(50.90 \mathrm{~km}^{2}\right)$, Lower lake $(62.00$ $\mathrm{km}^{2}$ ), water falls between the two lakes and springs, of which three are sulphur springs at the southern side of the lower lake, with extensive mobile sand dunes. It also embraces two mountains; Jabal Manqueer Al-Rayan at the south and southeast of the springs where marine fossils and archeological remains are found; and the other mountain is Jabal Madwera near the lower lake, which is known for its extensive dune formations. Additionally, Wadi ElRayan is one of the most important habitats for certain bird species of national, regional and international importance. 


\subsection{Wadi AlHitan protected area}

Wadi AlHitan (Whale Valley) is a paleontological site. It was designated a UNESCO World Heritage Site in 2005 for its hundreds of fossils of some of the earliest forms of whale. It is a remote valley where hundreds of fossil whale skeletons are being exposed by the wind. They lie trapped in a sandstone formation that represents an ancient sea bed. Wadi AlHitan is the only place in the world where the skeletons of families of archaic whales can be seen in their original geological and geographic setting of the shallow nutrient rich bay of a sea of some 40 million years ago.

In addition, a wider part of the Wadi AlRayan Protected Area is included in the property, including the immediate landscape surrounding the fossil sites, areas of scenic interest, and areas which provide visitor access and facilities. A buffer zone has been identified to protect the property from wider threats, including from visitation and traffic, and could be extended further in order to provide additional safeguards and to facilitate management.

Centuries of history has left indelible marks on AlFayoum mainly in the form of spectacular monuments and archaeological sites. However, one of the main sites of AlFayoum is Madinet Madi, a temple from Middle Kingdom, which has tremendous cultural significance. The other sites are Qasre Sagha, Dimeh and the oldest paved road in the world on the western side of Lake Qarun, Qasre Qarun, Hawara Pyramid and Coptic Monastery and Hanging Mosque of later periods are milestones for understanding the history of AlFaiyoum.

Although the uniqueness of AlFayum, as it combines integration between three environments; desert, coastal and agriculture and the protectorates represents approximately $80 \%$ of the total area of AlFayoum, it does not occupy a significant position on the touristic map of Egypt. AlFayoum has suffered from a continuous neglect from the government over the past decades, along with a tiny publicity effort exerted for promoting to its potentials which leads to a severe shortage in its tourism facilities and decreases its chance to compete with other touristic destinations in Egypt.

\section{Research methodology}

In order to achieve the objectives of this research, the methodology depends on presenting the potential ecotourism resources in AlFayoum and the expert panel technique. Semi-structured interviews were used to examine different views of the experts involved in the industry. Several experts working in the field of tourism and environmental affairs were selected. The selected experts were from the Tourism Development Authority, Environmental Affairs Egyptian Authority, Al Fayoum Governorate, professional from the private sector and those working in the management of the protected areas.

The main aim of the expert panel was to explore the environmental problems faced by AlFayoum and how these problems hinder the process of sustainable development. The expert panel is also asked to suggest appropriate policies and actions to apply ecotourism management techniques. 


\subsection{Problems faced by AlFayoum}

All the experts interviewed agreed upon the potential resources and opportunities for the ecotourism in the oasis mentioned in the previous section and they mentioned several problems facing the oasis and needs to be managed. These are:

- Although the lakes of AlFayoum were designated as protected area, the lake has hardly been protected from various polluting elements. It suffers from a serious water pollution problem which is due to uncontrolled solid and liquid domestic and industrial waste disposal practices, in addition lack of sustainable wastewater management. This situation has caused negative water use impacts on public health, environment, and socio-economic development.

- The exposed skeletons are fragile and vulnerable which makes it imperative that it should not be disturbed. They are exposed to wind erosion and burying by wind-carried sand, although fresh fossils are also exposed by the same process. They are more at danger from collectors who steal bones and fossil wood as souvenirs and saleable curiosities. As tourism increases visitors will require constant surveillance and monitoring: damage was done in 2007 by vehicles being driven over the skeletons by privileged foreigners. The wild landscape is scarred by vehicles tracks which are kept to a minimum.

- Environmental pollution of the lakes, however, may possibly have contributed to the gradual decline in the fisheries, at least in Lake Qarun. In addition, this pollution greatly impedes the use of the lake for water sports or swimming and reduces the chances of success for tourism development of the southern shore of Lake Qarun. Although, the eastern and western tips of Lake Qarun are specially designated as core zones of the bird sanctuary, tourism facilities and other buildings have been constructed directly on the shore line of the lake within the declared buffer zone. The construction work, site clearing, on-site wastewater and solid waste disposal, noise, obstruction of view to the lake causes a lot of damage to the bird habitats

- Many unexplored ruins from Pharaonic, Greco-Roman and Christian eras, are under threat by the illegal excavation by visitors and people from neighbouring areas in AlFayoum. All of these sites must be protected and remain undamaged to preserve the historical resources of AlFayoum.

- There is a noticeable shortage in the provision of accommodation and services in AlFayoum oasis. At the present time, no tourism facilities exist at the northern shore of Lake Qarun or in Wadi El Rayan except the desert safari camp on the lower Lake of Wadi Al Rayan. In the last decade, the tourism pattern was depending on the market of secondary housing units for domestic tourists especially from Cairo

- Although the several attempt to develop a number of Tourism Development Plans of AlFayoum Oasis, very few have been 
implemented. Issues of the regional economic crisis, conflicts between relevant authorities, lack of financial resources, environmental deterioration, language barriers, and availability of documents, local awareness and lack of specificity can be seen as some of the reasons for the difficulty and inability of implementation.

- AlFayoum suffers from lack of systems for collection and disposal of solid wastes at most villages, insufficiency of the number of collection vehicles, trash containers or collection workers at most cities and insufficiency of the numbers of dumpsites. Wastes are being disposed and burned randomly in some instances. Spread of diseases related to the problem of wastes, poor awareness of the rural residents of public health matters and hygiene

- The lacking of essential services and utilities in these random areas, especially those related to health and education, lead to the residents' exposure to poverty diseases connected with the pollution of the environment.

\subsection{Suggested principles and procedures to develop ecotourism}

The experts also agreed upon several strategies to develop ecotourism principles in AlFayoum. These are:

- Governments should also coordinate traditional policymaking between different ministries and areas of policy towards a joint effort to increase sustainability. This includes better understanding about the interplay between labour law and regulations with environmental regulation, land use, finance, agriculture, etc. In consultation with constituents, governments should gear the transformation of the tourism sector, along the whole economy, towards and integrated and harmonious system.

- Planning and upgrading infrastructure in accordance with the determined capacity of the natural area to receive a defined number of visitors (e.g., building a fixed number of cabins for the maximum allowable number of guests).

- Maintenance of an effective and well-resourced management plan, supported by adequate staff, finance and resources is an essential long term requirement. Amongst the key management issues are the protection, conservation and encouragement of well-managed research in relation to the natural values, to international standards of best practice. Other important long-term management needs are the continued protection of the property from damage by traffic of vehicles, the provision and maintenance of the essential management infrastructure within the property that minimizes intrusion and damage to its natural values, and the provision of facilities for sustainable tourism at appropriate levels of visitation. 
- Local residents of the oasis should be helped to develop skills in guiding visitors in the area, which includes many important areas for birds, and developing facilities for tourists such as eco-lodges.

- Develop and upgrade the environmental plant (EMISAL) that was constructed on in order to extract lake salts thereby reducing salinity down to ecologically accepted levels and extract mineral salts from the lake water which has the side benefits of reducing the lake's salinity levels.

- Develop an environment action plan to achieve balance in order to reach protection of the environment and economic development. The plan lays down the foundation for proper use of natural resources in the manner which ensures for the next generation harvesting the benefits of sound environmental management.

- The government should exert great efforts to enhance solid wastes management in the oasis through the adoption of numerous measures, including the construction of the solid wastes recycling factory, considered one of the biggest means of safe disposal of solid wastes, building two plants for relocating solid wastes.

- The achievement of sustainable achievements requires the construction of strong institutional structures and providing the necessary resources to accomplish the achievements. Moreover, the government should determine a number of measurable indicators to identify the progress of the governorate environment action plan activities. Further, the private sector companies should be encouraged to lay down administrative and individual goals. This will assist in achieving more efficiency and constructive exploitation of the limited resources in order to give more benefit and advanced environmental performance.

- The government should lay down a legal and economic framework to reinforce the participation of the private sector and investment in supplying and connecting the environment utility services. This will reduce the financial and administrative burden on the government and enhance the quality, coverage and connection of environmental services.

- An effective ecosystem management plan should be present in protected areas. Under this plan effective and well-designed visitor facilities should be provided to present the property, guide visitors to key localities via footpaths, prevent vehicular traffic in the property and provide for limited on-site accommodation. There should be planning team responsible for day-to-day management of the property, and the preparation of annual plans and monitoring and reporting on the effectiveness of its management.

- One of the major actions suggested by the panel is to launch and develop an initiative called "Friends of AlFayoum" with the aim of implementing fund raising and awareness campaign. This kind of collective organization is typical of modern ecotourism management 
to foster the link between the visitors and natural site through the supply of additional services newsletters and dedicated events.

- A proportion of tourism income should be essentially used for maintaining and protecting environmental tourism resources.

\section{Conclusion}

AlFayoum oasis should occupy a distinguishable position on Egypt Ecotourism map because of its blend of tourism resources. As a matter of fact, the oasis is facing several environmental problems. There is a need for proper ecotourism management procedures to address these problems and pave the way for environmentally sustainable and socio-economically viable use of these vital resources. The ecotourism management plan for the oasis must be a positive model for an ecologically sustainable and unique example of combining environment, local people, and development. Additionally, several parties are involved and affected by tourism performance, policy and planning. The most influential stakeholders in tourism from an environmental perspective are found to be the government, private sector organizations, tourists, competitors, employees and local community. However, most of stakeholders are from the private sector and the local community. Therefore, they should be environmentally aware. Indeed, the government should set a framework for collaboration to ensure maximum mutual benefits.

\section{References}

[1] Bly, L. Unrest in Egypt leaves tourism in ruins, USA Today, 2011.

[2] World Tourism Organization (WTO). Tourism highlights 2011, Madrid: WTO, 2011.

[3] Drum, A., Moore A., Soles, A., Patterson C., Terborch J., The Business of Ecotourism Development and Management, Volume II, The Nature Conservancy, Arlington, Virginia, USA, 2004.

[4] Tourism Western Australia, Ecotourism vs. Nature Based Tourism, Destination Development Coordinator, 2006.

[5] United Nations Environment Programme (UNEP), Industry as a partner for sustainable development, Second Edition, United Kingdom, 2011.

[6] Wong, P.P. ed. Tourism vs. environment: the case for coastal areas. Dordrecht: Kluwer Academic Publishers, 1993.

[7] Aronsson L., The Development of Sustainable Tourism, London: Continuum, 2000.

[8] Alvarez G., Jimenez M. and Lorente, J., An analysis of environmental management, organizational context and performance of Spanish hotels, The International Journal of Management Sciences, 457-471, 2001.

[9] Pásková, M., Sustainability of Tourism Development Prague, 2008.

[10] Antouskova, M., Kroupova, Z. and Cervena, G., Tourism Burden - Case Study of Southern Bohemia, The Business Review, Cambridge, 14(1), 186198, 2009. 
[11] Vaško, M., Tourism and Regional Development, Prague, 2002.

[12] Schmidheiny, S. Changing Course: A Global Business Perspective on Development and the Environment. Cambridge: The MIT Press, 1992.

[13] Egyptian Environmental Affairs Agency (EEAA), Environmental Action Plan of Fayoum Governorate. Cairo. Ministry of Environment, 2006.

[14] Environmental Management Unit (EMU) and Egyptian Environmental Affairs Agency (EEAA), Environmental Action Plan Fayoum Governorate, Fayoum Governorate and State Ministry of Environment, 2008.

[15] Santagata, W., Baig, S., Bertacchini, E., Cultural Systems and Local Sustainable Development Fayoum Oasis Egypt, Cultural Systems and Local Sustainable Development, 2012.

[16] Eraqi M., Ecotourism Resources Management as a Way for Sustainable Tourism Development in Egypt. Tourism Analysis, 12, 39-49, 2007.

[17] Tourism Development Authority (TDA), Best Practices for Tourism Center Development along the Red Sea Coast, Harvard Institute for International Development, Cairo, Egypt, 1998. 